\title{
Compatibility of different pesticides used for aphid and stripe rust control in wheat
}

Beant Singh and Jaspal Kaur

Punjab Agricultural University, Ludhiana, India

\section{Article history}

Received: 26-04-2017

Revised : 15-05-2017

Accepted: 19-06-2017

\section{Citation}

Singh B and J Kaur. 2017. Compatibility of different pesticides used for aphid and stripe rust control in wheat. Journal of Wheat Research 9(1): 54-59.

\section{*Corresponding author \\ Email:beant19@pau.edu}

(C) Society for Advancement of Wheat and Barley Research

\begin{abstract}
Wheat is the principal cereal crop of India and every year it suffers serious grain yield losses due to insect pest and diseases. In last few years, the simultaneous attacks of aphids and stripe rust were noticed during reproductive stages of wheat growth. As such the combination of different plant protection chemicals is not recommended, but combined application saves time, labour and money by reducing the number of sprays. Thus, it becomes inevitable for farmers to think about pesticide combinations when simultaneous appearance of disease and insect are confronted in the field. The compatibility of insecticide and fungicide mixture is a matter of great concern. The investigations were conducted to test the field efficacy and compatibility of some insecticides with broad spectrum fungicide propiconazole. The results of the studies clearly indicated that combinations of propiconazole with imidacloprid and thiamethoxam did not hinder their efficacy. However, the aphid control was significantly less (0-5.95 \%) when the combination of insecticide and fungicide were sprayed in 500 litres of spray volume as compared to 250 litres of spray volume per hectare. At the same time, reduction in coccinellid population was also less (2.48-8.96\%) when 500 litres of spray volume was used. The information from the study will help the farmers confronted with the combined attack of stripe rust and aphids in wheat growing regions of the country. The tested combinations can reduce cost of pesticide application in wheat crop and can also fit well in IPM programme.
\end{abstract}

Keywords : Compatibility, insecticides, propiconazole, aphid, stripe rust, control

\section{Introduction}

Wheat (Triticum aestivum L.) is one of the most important food crops in the world (Ortiz et al., 2008). Many insect pests have been reported to infest wheat worldwide. While most of these insects cause insignificant damage, others annually cause serious yield reduction across international borders (Miller and Pike, 2002). In India, wheat is the most important winter cereal crop and last year it was grown over 30.23 million hectare with an annual production of 93.50 million tonnes of food grains (Anonymous, 2016). Every year, it suffers serious grain yield losses due to insect pest and diseases. The annual monetary loss of Rs 413.68 billion has been reported due to insect pests in wheat from India (Dhaliwal et al., 2010). The wheat production in North-western plains of India is periodically impacted by several aphid species viz. Rhopalosiphum maidis (Fitch), Rhopalosiphum padi L., Sitobion miscanthi (Takahashi) and Sitobion avenae (Fabricius) (Deol et al., 1987). The aphid damage is seen during grain filling stage when both nymphs and adults take a heavy toll by sucking cell sap from leaves and maturing grains (Voss et al., 1997). The infested leaves turn pale, wilt and wear a stunted appearance and cause 3-21 per cent grain yield loss (Singh and Deol, 2003). Although a complex of natural enemies including lady bird bettle Coccinella septumpunctata 
Linnaeus, green lacewing Crysoperla carnea (Stephens), and syrphid flies are present in wheat ecosystem, yet the aphids control is largely dependent on application of insecticides.

In last few years, the severe incidence of stripe rust (Puccinia striformis) was also recorded during different stages of wheat growth (Jindal et al., 2012) . Sometimes, farmers are confronted with combined appearance of disease and insect attack. As such the combination of different plant protection chemicals is not recommended, but combined application saves time, labour and money by reducing the number of sprays. Thus, it becomes inevitable for farmers to think about pesticide combinations when combined appearance of disease and insect are confronted in the field. The compatibility of insecticide and fungicide mixture is a matter of great concern. Gray (1914) prepared a chart showing compatibility of some insecticide and fungicide. Later, several charts were developed or updated by Frear (1979), Guuzdyed et al. (1983) for chemicals in use at a particular time. Baicu (1980) suggested that pesticide compatibility should be studied in different stages including field test of effectiveness, phyto- toxicity and yield after treatments. Keeping in view the importance of the problem and lack of information, investigations were conducted to test the field efficacy and compatibility of some insecticides with broad spectrum fungicide propiconazole.

\section{Materials and methods}

The field experiments were conducted under irrigated conditions at Plant Breeding Research Farm, Punjab Agricultural University(PAU), Ludhiana (30 $55^{\prime} \mathrm{N} 75^{\circ}$ 54' $\mathrm{E}$ and $250 \mathrm{~m}$ above sea level) for two seasons, 2014-15 and 2015-16. The aphid and stripe rust susceptible wheat variety PBW 621 was selected for experimentation and it was sown in last week of November in both the years. The PAU recommended pesticides viz. imidacloprid (Confidor 17.8 SL, Bayer crop Science India), thiamethoxam (Actara 25 WG, Syngenta India Ltd.), propiconazole (Tilt 25 EC, Syngenta India Ltd.) were selected for investigations (Anonymous, 2014). The crop was raised by following recommended standard package of practices except for the usage of pesticides (Anonymous, 2014). The experiments were conducted in randomized complete block design
(RCBD) with eight different treatments. Each treatment was replicated thrice and the plots size was $6 \times 1.25 \mathrm{~m}^{2}$ $=7.5 \mathrm{~m}^{2}$. The treatments comprised of imidacloprid @ 100 ml/ha, thiamethoxam @ 50 ml/ha, propiconazole @ $500 \mathrm{ml} / \mathrm{ha}$ and their four different combinations along with untreated control. The combinations included mixing and spraying together of insecticide and fungicide in 250 and 500 litres of water. The pesticide applications were done with knapsack sprayer at heading stage when average aphid infestation reached 15-20 aphids per tiller along with the incidence of stripe rust. The aphids were transferred to experimental plots from mid-January onwards using detached leaf method (Verma et al., 2011). The inoculum of Puccinia striformis fsp. tritici was sprayed in the first fortnight of January to ensure the uniform spread of disease. The pesticide applications were done in the quiet evening hours to avoid drift problem.

For recording observations, five shoots were ear marked in each plot and from these plants observations were recorded one day before spray and then one, two, seven and fifteen days after spray. Only the live aphids were taken into account for counting the aphid population after application of treatment. The population of coccinellid beetle (both grubs and adults) was also recorded three days after spray while the per cent stripe rust severity was recorded seven days after pesticide application by using 0-9 scale given by Saari and Prescott, (1975). At maturity, grain yield was recorded on whole plot basis and converted to quintal per hectare. The data were subjected to analysis of variance (ANOVA) and pair-wise comparison of the means was done by using Duncan's multiple range test $(p=0.05)$. Analyses were done with Genstat 18 (Payne et al. 2015).

\section{Result and discussion}

The aphid infestation and grain yield differed significantly ( $p<0.001$ ) between 2014-2015 and 2015-2016, so years were analyzed separately. The average grain yield was significantly higher in 2014-15 as compared to 2015-2016 while aphid incidence was significantly higher in 20152016 than 2014-2015.

3.1 Year 2014-15:Aphid population did not differ significantly among all treatments one day before spray (Table 1). 
When observed one day after spray, imidacloprid sprayed plots (1.18 aphids/earhead) recorded significantly lower aphids than propiconazole sprayed plots (20.70 aphids/ earhead) and untreated control (21.76 aphids/earhead). Similarly, two, seven and fifteen days after treatments, aphid population was significantly lower in all treatments except foliar application of propiconazole (12.55-20.65 aphids/earhead) and untreated control (11.40-19.74 aphids/earhead). The severity of stripe rust was up to 10 per cent in treatments where propiconazole was applied alone or in combination with imidacloprid/thiamethoxam while it was 40-60 per cent in those treatments where only imidacloprid/thiamethoxam was applied. The severity of stripe rust was 60 per cent in untreated control. The insecticides alone or in combination with propiconazole resulted in significant reduction in coccinellid population (7.66-9.33/plot) as compared to untreated control (31.66/ plot). Interestingly, the application of propiconazole also resulted in significant reduction in coccinellid population (23.33/plot) as compared to untreated control (31.66/plot).

The combinations of insecticide and fungicide did not have any toxic effect on the wheat. The insecticides and fungicides did not lose their effectiveness as evident from 80-90 per cent disease and aphid control level. Maximum grain yield (63.11 q/ha) was recorded from the plots treated with combination of propiconazole + imidacloprid (5:1) in 500 litres of water and it was at par with all the mixed application of propiconazole and insecticides. The other treatment where only insecticides were applied recorded significantly lower grain yield than mixed application of fungicide and insecticides, however yield in these treatments were still significantly better than untreated control (45.95 q/ha).

Table 1. Compatibility of different insecticides used for aphid control with fungicide (2014-15)

\begin{tabular}{|c|c|c|c|c|c|c|c|c|c|c|}
\hline \multirow[t]{3}{*}{ Treatments } & \multicolumn{5}{|c|}{ Aphid population per earhead } & \multirow{2}{*}{$\begin{array}{l}\begin{array}{l}\text { Cocci- } \\
\text { nellid } \\
\text { /plot }\end{array} \\
\begin{array}{l}\text { After } \\
\text { spray }\end{array}\end{array}$} & \multirow{2}{*}{$\begin{array}{l}\text { Stripe } \\
\text { rust } \\
\text { sever- } \\
\text { ity }(\%)\end{array}$} & \multirow{2}{*}{$\begin{array}{l}\text { Per } \\
\text { cent } \\
\text { disease } \\
\text { control } \\
\text { over } \\
\text { check }\end{array}$} & \multirow{2}{*}{$\begin{array}{l}\text { Grain } \\
\text { Yield } \\
\text { (q/ha) }\end{array}$} & \multirow{2}{*}{$\begin{array}{l}\text { Cost : } \\
\text { Ben- } \\
\text { efit } \\
\text { ratio }\end{array}$} \\
\hline & \multirow{2}{*}{$\begin{array}{l}\begin{array}{l}\text { Before } \\
\text { spray }\end{array} \\
1 \text { day }\end{array}$} & \multicolumn{4}{|c|}{ After spray } & & & & & \\
\hline & & 1 day & 2 days & 7 days & 15 days & 3 days & 7 days & & & \\
\hline $\begin{array}{l}\text { Propiconazole @ } 500 \mathrm{ml} / \mathrm{ha} \\
\text { in } 500 \text { litres of water }\end{array}$ & $\begin{array}{c}21.60 \mathrm{a} \\
(4.74)\end{array}$ & $\begin{array}{c}20.70 \mathrm{a} \\
(4.58)\end{array}$ & $\begin{array}{c}20.65 \mathrm{a} \\
(4.65)\end{array}$ & $\begin{array}{l}18.04 \mathrm{a} \\
(4.35)\end{array}$ & $\begin{array}{l}12.55 \mathrm{a} \\
(3.67)\end{array}$ & $\begin{array}{c}23.33 \mathrm{~b} \\
(4.91)\end{array}$ & 5.0 & 91.7 & $57.33 b$ & $1: 20.0$ \\
\hline $\begin{array}{l}\text { Imidacloprid @ } 100 \text { ml/ha } \\
\text { in } 250 \text { litres of water }\end{array}$ & $\begin{array}{c}21.80 \mathrm{a} \\
(4.74)\end{array}$ & $\begin{array}{l}1.18 \mathrm{~b} \\
(1.47)\end{array}$ & $\begin{array}{c}1.13 \mathrm{c} \\
(1.45)\end{array}$ & $\begin{array}{l}1.06 \mathrm{~b} \\
(1.42)\end{array}$ & $\begin{array}{l}0.40 \mathrm{~b} \\
(1.18)\end{array}$ & $\begin{array}{l}0.40 \mathrm{~b} \\
(1.18)\end{array}$ & $40-60$ & $0-33.3$ & $52.22 \mathrm{c}$ & 1: 17.6 \\
\hline $\begin{array}{l}\text { Thiamethoxam @ } 50 \mathrm{ml} / \mathrm{ha} \\
\text { in } 250 \text { litres of water }\end{array}$ & $\begin{array}{c}20.40 \mathrm{a} \\
(4.55)\end{array}$ & $\begin{array}{l}1.22 \mathrm{~b} \\
(1.49)\end{array}$ & $\begin{array}{l}1.19 \mathrm{c} \\
(1.48)\end{array}$ & $\begin{array}{l}0.95 \mathrm{~b} \\
(1.39)\end{array}$ & $\begin{array}{l}0.29 \mathrm{~b} \\
(1.13)\end{array}$ & $\begin{array}{l}8.33 \mathrm{c} \\
(3.02)\end{array}$ & 60.0 & 0.00 & $52.53 \mathrm{c}$ & 1: 21.6 \\
\hline $\begin{array}{l}\text { Propiconazole + Imidaclo- } \\
\text { prid @ } 100 \mathrm{ml} / \mathrm{ha} \text { in } 250 \\
\text { litres of water }\end{array}$ & $\begin{array}{c}20.80 \mathrm{a} \\
(4.63)\end{array}$ & $\begin{array}{l}1.55 \mathrm{~b} \\
(1.59)\end{array}$ & $\begin{array}{l}1.35 \mathrm{c} \\
(1.53)\end{array}$ & $\begin{array}{l}1.28 \mathrm{~b} \\
(1.50)\end{array}$ & $\begin{array}{l}0.25 \mathrm{~b} \\
(1.11)\end{array}$ & $\begin{array}{l}9.00 \mathrm{c} \\
(3.14)\end{array}$ & $5-10$ & $\begin{array}{c}83.3- \\
91.7\end{array}$ & $58.22 \mathrm{ab}$ & 1: 17.1 \\
\hline $\begin{array}{l}\text { Propiconazole + Thiameth- } \\
\text { oxam @ } 50 \mathrm{ml} / \mathrm{ha} \text { in } 250 \\
\text { litres of water }\end{array}$ & $\begin{array}{c}19.46 \mathrm{a} \\
(4.51)\end{array}$ & $\begin{array}{l}1.51 \mathrm{~b} \\
(1.58)\end{array}$ & $\begin{array}{l}1.33 \mathrm{c} \\
(1.52)\end{array}$ & $\begin{array}{l}1.19 \mathrm{~b} \\
(1.47)\end{array}$ & $\begin{array}{l}0.31 \mathrm{~b} \\
(1.14)\end{array}$ & $\begin{array}{l}9.00 \mathrm{c} \\
(3.15)\end{array}$ & $5-10$ & $\begin{array}{c}83.3- \\
91.7\end{array}$ & $58.62 \mathrm{ab}$ & 1: 19.0 \\
\hline $\begin{array}{l}\text { Propiconazole + Imidaclo- } \\
\text { prid @ } 100 \mathrm{ml} / \text { ha in } 500 \\
\text { litres of water }\end{array}$ & $\begin{array}{c}23.06 \mathrm{a} \\
(4.89)\end{array}$ & $\begin{array}{l}1.77 \mathrm{~b} \\
(1.66)\end{array}$ & $\begin{array}{l}1.40 \mathrm{c} \\
(1.54)\end{array}$ & $\begin{array}{l}1.26 \mathrm{~b} \\
(1.50)\end{array}$ & $\begin{array}{l}0.29 \mathrm{~b} \\
(1.13)\end{array}$ & $\begin{array}{l}8.00 \mathrm{c} \\
(2.97)\end{array}$ & 5.0 & 91.7 & $63.11 \mathrm{a}$ & $1: 25.6$ \\
\hline $\begin{array}{l}\text { Propiconazole + Thiameth- } \\
\text { oxam @ } 50 \mathrm{ml} / \text { ha in } 500 \\
\text { litres of water }\end{array}$ & $\begin{array}{c}21.26 \mathrm{a} \\
(4.71)\end{array}$ & $\begin{array}{l}1.89 \mathrm{~b} \\
(1.69)\end{array}$ & $\begin{array}{l}1.44 \mathrm{c} \\
(1.56)\end{array}$ & $\begin{array}{l}1.16 \mathrm{~b} \\
(1.47)\end{array}$ & $\begin{array}{l}0.36 \mathrm{~b} \\
(1.15)\end{array}$ & $\begin{array}{l}7.66 \mathrm{c} \\
(2.93)\end{array}$ & $5-10$ & $\begin{array}{c}83.3- \\
91.7\end{array}$ & $62.08 \mathrm{a}$ & 1: 24.2 \\
\hline Control & $\begin{array}{c}21.73 \mathrm{a} \\
(4.76)\end{array}$ & $\begin{array}{c}21.76 \mathrm{a} \\
(4.76)\end{array}$ & $\begin{array}{l}17.94 \mathrm{~b} \\
(4.34)\end{array}$ & $\begin{array}{l}16.06 \mathrm{a} \\
(4.12)\end{array}$ & $\begin{array}{l}11.40 \mathrm{a} \\
(3.51)\end{array}$ & $\begin{array}{c}31.66 \mathrm{a} \\
(5.70)\end{array}$ & 60.0 & 0.0 & $45.95 \mathrm{~d}$ & - \\
\hline
\end{tabular}

* Figures within parentheses are $\sqrt{ } \mathrm{n}+1$ transformed means; ** Cost of pesticide treatment $=$ Cost of pesticide + Labour charges @ Rs $300 /$ ha; ${ }^{* * *}$ Rates of pesticides $=$ imidacloprid $=$ Rs $2150 /$ litre thiamethoxam $=$ Rs $2842 / \mathrm{kg}$; propiconazole $=$ Rs $1050 / \mathrm{lt}$; $* * * *$ Market price of wheat @ Rs 1450/q. 
3.2 Year 2015-2016: The data presented in Table 2 indicated that statistical differences among treatments were significant immediately after one day of spray in all treatments. Minimum aphids (2.01 aphids/earhead)were recorded in imidacloprid sprayed plots and these were significantly lower than plots sprayed with propiconazole (27.06 aphids/earhead) as well as untreated control(24.36 aphids/earhead). Similarly, two, seven and fifteen days after treatments, aphid population was significantly lower in all the treatments except foliar application of propiconazole (13.76-26.40 aphids/earhead) and untreated control (12.70-26.16 aphids/earhead). Until seven days after treatment, it has been observed that aphid control was significantly less $(0-5.95 \%)$ when the combination of insecticide and fungicide were sprayed in 500 litres of water per hectare as compared to their combination in
250 litres of water. However, fifteen days after treatment, there was no such difference in aphid control between pesticide combinations in 250 and 500 litres of spray volumes per hectare. The severity of stripe rust varied from 0-10 per cent in treatments where propiconazole was applied alone or in combination with imidacloprid/ thiamethoxam whereas it was 20-40 per cent in those treatments where only imidacloprid/thiamethoxam was applied. The incidence of stripe rust was 40 per cent in untreated control. As in 2014-15, all pesticide applications resulted in significant reduction in coccinellid population as compared to untreated control (27/plot). The reduction in coccinellid population was comparatively less (2.48$8.96 \%$ ) when 500 litres of spray volume was used for application of combination of insecticide and fungicide as compared to 250 litres spray volume.

Table 2. Compatibility of different insecticides used for aphid control with fungicide (2015-16)

\begin{tabular}{|c|c|c|c|c|c|c|c|c|c|c|}
\hline \multirow[t]{3}{*}{ Treatments } & \multicolumn{5}{|c|}{ Aphid population per earhead } & \multirow{2}{*}{$\begin{array}{l}\begin{array}{l}\text { Cocci- } \\
\text { nellid } \\
\text { /plot }\end{array} \\
\begin{array}{l}\text { After } \\
\text { spray }\end{array} \\
\end{array}$} & \multirow{2}{*}{$\begin{array}{l}\text { Stripe } \\
\text { rust } \\
\text { sever- } \\
\text { ity }(\%)\end{array}$} & \multirow{2}{*}{$\begin{array}{l}\text { Per } \\
\text { cent } \\
\text { disease } \\
\text { control } \\
\text { over } \\
\text { check }\end{array}$} & \multirow{2}{*}{$\begin{array}{l}\text { Grain } \\
\text { Yield } \\
\text { (q/ha) }\end{array}$} & \multirow{2}{*}{$\begin{array}{l}\text { Cost : } \\
\text { Ben- } \\
\text { efit } \\
\text { ratio }\end{array}$} \\
\hline & \multirow{2}{*}{$\begin{array}{l}\begin{array}{l}\text { Before } \\
\text { spray }\end{array} \\
1 \text { day }\end{array}$} & \multicolumn{4}{|c|}{ After spray } & & & & & \\
\hline & & 1 day & 2 days & 7 days & 15 days & 3 days & 7 days & & & \\
\hline $\begin{array}{l}\text { Propiconazole @ } 500 \mathrm{ml} / \text { ha } \\
\text { in } 500 \text { litres of water }\end{array}$ & 25.23 & $\begin{array}{r}27.06 \mathrm{a} \\
(5.29)\end{array}$ & $\begin{array}{c}26.40 \mathrm{a} \\
(5.23)\end{array}$ & $\begin{array}{c}19.53 \mathrm{a} \\
(4.52)\end{array}$ & $\begin{array}{l}13.76 \mathrm{a} \\
(3.82)\end{array}$ & $\begin{array}{c}19.66 \mathrm{~b} \\
(4.54)\end{array}$ & 5.0 & 87.5 & $50.80 \mathrm{a}$ & 1: 12.7 \\
\hline $\begin{array}{l}\text { Imidacloprid @ } 100 \text { ml/ha } \\
\text { in } 250 \text { litres of water }\end{array}$ & 24.66 & $\begin{array}{l}2.01 \mathrm{~d} \\
(1.73)\end{array}$ & $\begin{array}{l}1.51 \mathrm{c} \\
(1.58)\end{array}$ & $\begin{array}{l}1.01 \mathrm{c} \\
(1.41)\end{array}$ & $\begin{array}{l}0.50 \mathrm{~b} \\
(1.22)\end{array}$ & $\begin{array}{l}8.66 \mathrm{c} \\
(3.09)\end{array}$ & $20-40$ & $0-50.0$ & $47.15 \mathrm{~b}$ & 1: 9.47 \\
\hline $\begin{array}{l}\text { Thiamethoxam @ } 50 \mathrm{ml} / \mathrm{ha} \\
\text { in } 250 \text { litres of water }\end{array}$ & 24.43 & $\begin{array}{l}2.08 \mathrm{~d} \\
(1.75)\end{array}$ & $\begin{array}{l}1.45 \mathrm{c} \\
(1.56)\end{array}$ & $\begin{array}{l}0.93 c \\
(1.38)\end{array}$ & $\begin{array}{l}0.49 \mathrm{~b} \\
(1.22)\end{array}$ & $\begin{array}{l}9.66 \mathrm{c} \\
(3.26)\end{array}$ & $20-40$ & $0-50.0$ & $47.02 \mathrm{~b}$ & 1: 10.6 \\
\hline $\begin{array}{l}\text { Propiconazole + Imidaclo- } \\
\text { prid @ } 100 \mathrm{ml} / \mathrm{ha} \text { in } 250 \\
\text { litres of water }\end{array}$ & 25.06 & $\begin{array}{l}1.98 \mathrm{~d} \\
(1.72)\end{array}$ & $\begin{array}{l}1.44 \mathrm{c} \\
(1.55)\end{array}$ & $\begin{array}{l}0.98 \mathrm{c} \\
(1.40)\end{array}$ & $\begin{array}{l}0.37 \mathrm{~b} \\
(1.16)\end{array}$ & $\begin{array}{l}9.33 \mathrm{c} \\
(3.20)\end{array}$ & 5.0 & 87.5 & $51.95 \mathrm{a}$ & 1: 11.7 \\
\hline $\begin{array}{l}\text { Propiconazole }+ \text { Thiameth- } \\
\text { oxam @ } 50 \mathrm{ml} / \text { ha in } 250 \\
\text { litres of water }\end{array}$ & 23.96 & $\begin{array}{l}2.09 \mathrm{~d} \\
(1.75)\end{array}$ & $\begin{array}{l}1.65 \mathrm{c} \\
(1.62)\end{array}$ & $\begin{array}{l}0.91 \mathrm{c} \\
(1.38)\end{array}$ & $\begin{array}{l}0.31 \mathrm{~b} \\
(1.16)\end{array}$ & $\begin{array}{l}8.00 \mathrm{c} \\
(2.98)\end{array}$ & 5.0 & 87.5 & $52.31 \mathrm{a}$ & 1: 13.2 \\
\hline $\begin{array}{l}\text { Propiconazole + Imidaclo- } \\
\text { prid @ } 100 \mathrm{ml} / \mathrm{ha} \text { in } 500 \\
\text { litres of water }\end{array}$ & 25.90 & $\begin{array}{l}3.52 \mathrm{c} \\
(2.12)\end{array}$ & $\begin{array}{l}2.48 \mathrm{~b} \\
(1.86)\end{array}$ & $\begin{array}{l}1.92 \mathrm{~b} \\
(1.70)\end{array}$ & $\begin{array}{l}0.34 \mathrm{~b} \\
(1.15)\end{array}$ & $\begin{array}{l}7.00 \mathrm{c} \\
(2.81)\end{array}$ & 5.0 & 87.5 & $53.60 \mathrm{a}$ & 1: 14.1 \\
\hline $\begin{array}{l}\text { Propiconazole + Thiameth- } \\
\text { oxam @ } 50 \mathrm{ml} / \text { ha in } 500 \\
\text { litres of water }\end{array}$ & 25.30 & $\begin{array}{l}3.54 \mathrm{c} \\
(2.13)\end{array}$ & $\begin{array}{l}2.57 \mathrm{~b} \\
(1.88)\end{array}$ & $\begin{array}{l}1.85 \mathrm{~b} \\
(1.68)\end{array}$ & $\begin{array}{c}0.27 \mathrm{~b} \\
(1.12)\end{array}$ & $\begin{array}{c}7.33 \mathrm{c} \\
(2.85)\end{array}$ & 5.0 & 87.5 & $53.20 \mathrm{a}$ & 1: 14.6 \\
\hline Control & 26.76 & $\begin{array}{c}24.36 \mathrm{~b} \\
(5.03)\end{array}$ & $\begin{array}{c}26.16 \mathrm{a} \\
(5.20)\end{array}$ & $\begin{array}{c}20.60 \mathrm{a} \\
(4.63)\end{array}$ & $\begin{array}{l}12.70 \mathrm{a} \\
(3.68)\end{array}$ & $\begin{array}{c}27.00 \mathrm{a} \\
(5.27)\end{array}$ & 40 & 0 & $43.95 c$ & 1 \\
\hline
\end{tabular}

* Figures within parentheses are $\sqrt{ } \mathrm{n}+1$ transformed means; ** Cost of pesticide treatment= Cost of pesticide + Labour charges @ Rs $300 / \mathrm{ha}$; ${ }^{* * *}$ Rates of pesticides = imidacloprid = Rs 2150/litre; thiamethoxam = Rs 2842/kg; propiconazole = Rs 1050/litre; ${ }^{* * *}$ Market price of wheat@ Rs 1525/q 
Grain yield (53.60 q/ha) obtained was maximum in combination of propiconazole + imidacloprid (5:1) mixed in 500 litres of water and it was at par with all the mixed application of propiconazole and insecticides as well as application of propiconazole alone $(50.80 \mathrm{q} / \mathrm{ha})$. The other treatments where only insecticides were applied, recorded significantly lower grain yield (47.02-47.15 q/ha) than mixed application of propiconazole and insecticides (51.95-53.60 q/ha).

The results of the studies clearly indicated that combinations of propiconazole with imidacloprid or thiamethoxam did not hinder their efficacy. The insecticide and fungicide alone or in combinations proved highly effective in controlling the wheat aphids and stripe rust. These findings are consistent with previous study that demonstrated the compatibility of imidacloprid and propiconazole as foliar application for aphid management (Babu and Sharma, 2003). There was significant reduction in aphid population in all pesticide combinations as compared to untreated control during 2014-2015. However, in 2015-2016, aphid control was significantly less when the combination of insecticide and fungicide were sprayed in 500 litres of spray volume as compared to 250 litres of spray volume per hectare. At the same time, reduction in coccinellid population was also less when 500 litres of spray volume was used. This could be due to the reduction in concentration of active ingredient of insecticide in 500 litres of spray volume which favoured the survival of aphids and their coccinellid predators. The significant reduction in coccinellid population with the application of propiconazole is a matter of great concern. Although some information on the harmful effect of fungicide on insect population is available in literature (Martinson et al., 2001; and Michaud, 2001), but a thorough laboratory investigation in this regard is required to ascertain their ill effects on natural enemies.

Overall, it can be concluded that combination propiconazole and imidacloprid/ thiamethoxam was highly effective in reducing aphid infestation and stripe rust severity. The information from the study will be useful for the farmers as the simultaneous emergence of stripe rust and aphids is becoming more common in wheat growing regions of the country. Hence, these tested new combinations (propiconazole + insecticides in 500 litres of water per hectare) can reduce cost of pesticide application in wheat crop and can also fit well in IPM programme.

\section{References}

1. Anonymous. 2014. Package of practices for crops of Punjab. Rabi. Punjab Agricultural University, Ludhiana. pp.1-17.

2. Anonymous. 2016. Progress Report of All India Coordinated Wheat and Barley Improvement Project 2015-16, Project Director's Report. Ed: GP Singh, DWR, Karnal, India, p.96.

3. Babu KS and AK Sharma. 2003. Compatibility of a newer insecticide, imidacloprid (Confidor) with propiconazole (Tilt $25 \mathrm{EC}$ ) against foliar aphids and their coccinellid predators of wheat ecosystem. Indian Journal of Entomology 65: 287- 291.

4. Baicu T. 1980. Study and classification of the compatibility of pesticides. Problems in Plant Protection 6: 271-279.

5. Deol GS, KS Gill and JS Brar. 1987. Aphid outbreak on wheat and barley in Punjab. Newsletter Aphidological Soc., India, 6: 7-9.

6. Dhaliwal GS, V Jindal and AK Dhawan. 2010. Insect Pest Problems and Crop Losses: Changing Trends. Indian Journal of Ecology 37: 1-7.

7. Frear DEH. 1979. Compatibility of common spray materials. Agricultural Chemicals 4:25-28.

8. Gray P. 1914. The compatibility of insecticides and fungicides. Monthly bulletin of California.

9. Gruzdyed GS, VA Zinchenko, VA Kalilin and RI Soutsov. 1983. The chemical protection of plants. pp. 438-443.

10. Jindal MM, C Mohan and PPS Pannu. 2012. Status of stripe rust of wheat in Punjab during 2011-12 seasons. Proceedings of Brain storming session, Department of Plant Pa-thology, PAU, Ludhiana, pp.56.

11. Martinson T, L Williams III and G English-Loeb. 2001. Compatibility of chemical disease and insect management pratcies used in New York vineyard with biological control by Anagrus spp. (Hymenoptera: Mymaridae), parasitoids of Erythroneura leafhopper. Biological Control 22: 227-234.

12. Michaud JP. 2001. Response of two ladybeetles to eight fungicides used in Florida citrus: implications for biological control. Journal of Insect Science 1:1-6. 
13. Miller RH and KS Pike. 2002. Insects in wheatbased systems. In: Curtis BC, Rajaram S, Gómez Macpherson $\mathrm{H}$ (eds) Bread wheat: improvement and production, plant production and protection series no. 30, FAO, Rome, pp 367-393.

14. Ortiz R, H J Braun, J Crossa, JH Crouch, G Davenport, J Dixon, S Dreisigacker, E Duveiller, Z He, J Huerta. 2008. Wheat genetic resources enhancement by International Maize and Wheat Improvement Centre(CIMMYT). Genetic Resources and Crop Evolution. 55:1095-1140.

15. Payne R, S Welham and S Harding. 2015. A Guide to GenStat. http://www.-genstat.co.uk/ (accessed 12 December 2016).

16. Saari EE and JM Prescott. 1975. A scale for appraising the foliar intensity of wheat diseases. Plant Disease Reporter 59: 377-380
17. Singh B and GS Deol. 2003. Quantative grain yield losses caused by aphid complex in wheat. Crop Research 26: 501-504.

18. Verma RPS, R Malik, R Kumar and SS Singh 2011. Genetics of corn leaf aphid (Rhopalosiphum maidis) resistance in barley. Cereal Research Communication 39: 130-36.

19. Voss TS, RW Kieckhefer, BW Fuller, MJ McLeod and DA Beck. 1997. Yield losses in maturing spring wheat caused by cereal aphids (Homoptera: Aphididae) under laboratory conditions. Journal of Economic Entomology 90:1346-1350. 